\title{
Effect of calcium fertilization on silver vase bromeliad (Aechmea fasciata)
}

\author{
Claus Baumgarten Milioni' ${ }^{1}$, Lucas Hiroshi Kawakubo², Renato Jocys Kanashiro ${ }^{3}$, \\ Vanessa Rebouças dos Santos ${ }^{1 *}$, Shoey Kanashiro ${ }^{1}$, Armando Reis Tavares ${ }^{1}$
}

\begin{abstract}
The present study aimed to evaluate the effect of different concentrations of calcium on growth and development of silver vase bromeliad (Aechmea fasciata). Plants were fertilized three times a week with nutrient solutions formulated with HA solution (Hoagland and Arnon, 1950) modified with $0.25,2.5,5,7.5,10.0$ or $12.5 \mathrm{mM} \mathrm{Ca}$ applied into the tank. After 90 days of experimentation, biometric and biomass measurements of root and shoot systems, and chemical analysis of leaves were assessed. The results showed that the concentration of $12.5 \mathrm{mM} \mathrm{Ca}$ in nutrient solution is recommended for silver vase bromeliad fertilization. Keywords: Bromeliaceae, plant nutrition, fertilization, calcium nitrate.

\section{Resumo}

Efeito da adubação com cálcio na bromélia Aechmea fasciata

O presente estudo teve como objetivo avaliar o efeito de diferentes concentrações de cálcio no crescimento e desenvolvimento da bromélia ornamental Aechmea fasciata. As plantas foram fertilizadas três vezes por semana com soluções nutritivas de HA (Hoagland and Arnon, 1950) modificadas com 0,25; 2,5; 5; 7,5; 10,0 ou 12,5 mM de Ca aplicadas no tanque. Após 90 dias de experimentação, foram avaliadas as variáveis biométricas e de biomassa do sistema radicular e da parte aérea e teor de nutrientes na folha. Os resultados mostraram que a concentração de 12,5 $\mathrm{mM}$ de Ca na solução nutritiva é recomendada para a fertilização da bromélia ornamental Aechmea fasciata.
\end{abstract}

Palavras-chave: Bromeliaceae, Nutrição mineral, adubação, nitrato de cálcio.

\section{Introduction}

The importance of bromeliads as ornamental plants has increased in recent decades (Anacleto and Negrelle, 2009). Cultivated initially in botanical gardens, bromeliads have become very popular into worldwide as ornamental due to the beautiful shapes and colors of leaves and inflorescences, low maintenance and its use as vase plant or for landscape (Negrelle and Anacleto, 2012). However, there is a lack of information about plant nutrition, substrate and, insect and diseases control on the production of bromeliads for commercial purposes, which would promote an increase in productivity and quality of the crop.

The leaves of the bromeliads are adapted to absorb nutrients and water through structures such as hairs and foliar trichrome (Englert, 2000). The balanced fertilization on bromeliads produces better quality plants and resistance to diseases and pests (Kanashiro et al., 2007). Calcium is a crucial regulator of plants growth and development, and participates of numerous processes, involving almost all aspects in plant life (Hepler, 2005). Calcium is important on inflorescence differentiation and fruits development of bromeliads such as pineapple (Ananas comosus (L.) Merr.) and supports transpiration without loss of turgescence; while excessive levels of the element reduce potassium in leaves, initiate chlorosis and produce smaller plants (Paula et al., 1998). The first symptoms of calcium deficiency in Ananas comosus var. erectifolius initiate on new leaves, which develop light green color on the blade and edge of the leaves, along with reduction of plant height and size of leaves (Viégas et al., 2014). Pineapple plants demands high quantities of $\mathrm{Ca}$; conversely, except in very poor and sandy soils deficiency rarely occurs (Py et al., 1987) and the most important effect of $\mathrm{Ca}$ is on fruit quality (Souza and Reinhard, 2007). The present study aimed to evaluate the effect of different concentrations of calcium on growth and development of silver vase bromeliad.

\footnotetext{
${ }^{1}$ Instituto de Botânica (IBt), São Paulo-SP, Brazil. * Corresponding author: vrsantos@ibot.sp.gov.br

${ }^{2}$ Faculdade de Engenharia de Ilha Solteira (FEIS-UNESP), Ilha Solteira-SP, Brazil.

${ }^{3}$ Universidade de São Paulo (USP), Instituto de Química (IQ), São Paulo-SP, Brazil.

Received May 30, 2018 | Accepted May 17, 2019

Licensed by CC BY 4.0

http://dx.doi.org/10.14295/oh.v25i2.1230
} 


\section{Material and methods}

The experiment was conducted at São Paulo City ( $23^{\circ} 30^{\prime}$ S and 46 $\left.40^{\circ} \mathrm{W}\right)$, São Paulo State, Brazil, positioned $770 \mathrm{~m}$ over sea level. The plants used in the experiment were approximately 6 months old (average of 9.8 leaves, leaf length of $15.21 \mathrm{~cm}$, root length of $5.84 \mathrm{~cm}$, and $5.80 \mathrm{~g}$ of total fresh weight, $\mathrm{n}=10$ ) and were transplanted to 1.25 L black polyethylene pots, containing composted Pinus bark as substrate. The study was conducted in a greenhouse with a transparent polyethylene cover with average daily irradiance of $530 \mu \mathrm{mol} \mathrm{m} \mathrm{m}^{-2} \mathrm{~s}^{-1}$ and irrigation through microsprinkler (NaanDanJain $\AA$, Modular Micro-Sprinkler 141 $\mathrm{L} \mathrm{h}^{-1}$ ) in two 15 minutes daily regimes. The analysis of irrigation water showed $\mathrm{pH}$ - 7.7; RAS (sodium absorption ratio) - 0.23; EC - $0.080 \mathrm{dS} \mathrm{m} \mathrm{m}^{-1}$; ions in mmol $\mathrm{L}^{-1} ; \mathrm{K}^{+}$$0.07 ; \mathrm{Ca}^{++}=0.320 ; \mathrm{Mg}^{++}=0.060 ; \mathrm{Cl}^{-}=0.960 ; \mathrm{Na}^{+}=0.100$; $\mathrm{CO}_{3}^{-2}=0.000$ and $\mathrm{HCO}_{3}-0.420$.

Plants were treated with HA solution (Hoagland and Arnon, 1950) modified with $0.25,2.5,5,7.5,10.0$ or 12.5 $\mathrm{mM} \mathrm{Ca}$. The macronutrients concentrations were balanced to maintain the ions concentrations as in the HA solution (Table 1). The $\mathrm{pH}$ of the solutions was adjusted to 5.8, and the plants received $30 \mathrm{~mL}$ of the solution three times a week into the tank. The treatments were distributed in a completely randomized block design with four blocks containing 6 treatments each with 5 plants per plot, totaling 120 plants.

Table 1. Ions and source and concentrations in molarity units to formulate ionic balanced Hoagland and Arnon solution n.1 (1950) with $0.25,2.5,5,7.5,10$ or $12.5 \mathrm{mM} \mathrm{Ca}$.

\begin{tabular}{|c|c|c|c|c|c|c|}
\hline \multirow{2}{*}{ Ion/source } & \multicolumn{6}{|c|}{ Concentration (mM) } \\
\hline & 0.25 & 2.5 & 5.0 & 7.5 & 10.5 & 12.5 \\
\hline $\mathrm{NO}_{3}^{-}-\mathrm{KNO}_{3}$ & 4.5 & 4.5 & 4.5 & 4.5 & 4.5 & 4.5 \\
\hline $\mathrm{NO}_{3}-\mathrm{Ca}\left(\mathrm{NO}_{3}\right)_{2} \cdot 4 \mathrm{H}_{2} \mathrm{O}$ & 0.5 & 5.00 & 10.00 & 15.00 & 20.00 & 25.00 \\
\hline $\mathrm{NO}_{3}^{-}-\mathrm{NH}_{4} \mathrm{NO}_{3}$ & 12.5 & 10.25 & 7.75 & 5.25 & 2.75 & 0.25 \\
\hline $\mathrm{NH}_{4}^{+}-\mathrm{NH}_{4} \mathrm{NO}_{3}$ & 12.5 & 10.25 & 7.75 & 5.25 & 2.75 & 0.25 \\
\hline N-total & 30 & 30 & 30 & 30 & 30 & 30 \\
\hline $\mathrm{PO}_{4}^{3-}-\mathrm{KH}_{2} \mathrm{PO}_{4}$ & 1.5 & 1.5 & 1.5 & 1.5 & 1.5 & 1.5 \\
\hline $\mathrm{K}^{+}-\mathrm{KNO}_{3}$ & 4.5 & 4.5 & 4.5 & 4.5 & 4.5 & 4.5 \\
\hline $\mathrm{K}^{+}-\mathrm{KH}_{2} \mathrm{PO}_{4}$ & 1.5 & 1.5 & 1.5 & 1.5 & 1.5 & 1.5 \\
\hline $\mathrm{K}^{+}$total & 6 & 6 & 6 & 6 & 6 & 6 \\
\hline $\mathrm{Ca}^{2+}-\mathrm{Ca}\left(\mathrm{NO}_{3}\right)_{2} \cdot 4 \mathrm{H}_{2} \mathrm{O}$ & 0.25 & 2.5 & 5.0 & 7.5 & 10.0 & 12.5 \\
\hline $\mathrm{Ca}^{2+}$-total & 0.25 & 2.5 & 5.0 & 7.5 & 10.0 & 12.5 \\
\hline $\mathrm{Mg}-\mathrm{MgSO}_{4} \cdot 7 \mathrm{H}_{2} \mathrm{O}$ & 2.0 & 2.0 & 2.0 & 2.0 & 2.0 & 2.0 \\
\hline $\mathrm{SO}_{4}-\mathrm{MgSO}_{4} \cdot 7 \mathrm{H}_{2} \mathrm{O}$ & 2.0 & 2.0 & 2.0 & 2.0 & 2.0 & 2.0 \\
\hline
\end{tabular}

After 90 days of experimentation, plants were measured from substrate level to highest leaf (plant height) and measured diameter of the stem (substrate level). Plants were harvested from pots and sectioned into leaves, roots and stem. The width of the largest leaf was measured and number of leaves counted. The leaves, stem, root and total fresh mass were weighted, then dried at forced-air oven 70 ${ }^{\circ} \mathrm{C}$ until constant weight for dry mass.

The analysis of mineral elements was performed on all dried leaves that were powdered in mill according to Malavolta et al. (1997). Samples were subjected to nitric-perchloric acid digestion and phosphorus contents were determined by the metavanadate colorimetric method, potassium by flame spectrophotometry, calcium, magnesium, zinc, iron, copper and manganese by atomic absorption spectrometer and sulfur by turbidimetry of barium sulphate. Nitrogen contents were evaluated by Kjeldahl method and boron was assessed by the azomethine-H method.

For statistical analyses, data were analyzed by regression, and the adjustment degree of the models was evaluated by the significance of regression coefficients using F-test $(p \leq 0.05)$ using Sisvar Software. When not statistically significant for first, second or third-degree regression, the data average $(\bar{y})$ with its value was inserted as a straight line in the graphic.

\section{Results and discussion}

The increase of $\mathrm{Ca}$ in HA modified solution had an increment effect on variables plant height $(\mathrm{p} \leq 0.05)$, stem diameter $(\mathrm{p} \leq 0.05)$, leave fresh $(\mathrm{p} \leq 0.05)$ and dry $(\mathrm{p} \leq$ 
$0.05)$ masses, and total plant fresh $(\mathrm{p} \leq 0.05)$ and dry $(\mathrm{p} \leq$ 0.05 ) masses of silver vase bromeliad. The optimum $\mathrm{Ca}$ concentration (maximum point) with highest stem diameter (22.21 millimeters) was $7.83 \mathrm{mM} \mathrm{Ca}$ (Figure 1A). Plant height (Figure 1B) significantly increased with the addition of calcium. Data for leaf width and number of leaves (Figures $1 C$ and $1 D)$ were not significant $(p>0.05)$ with increasing calcium concentration in silver vase bromeliad cultivation.

A
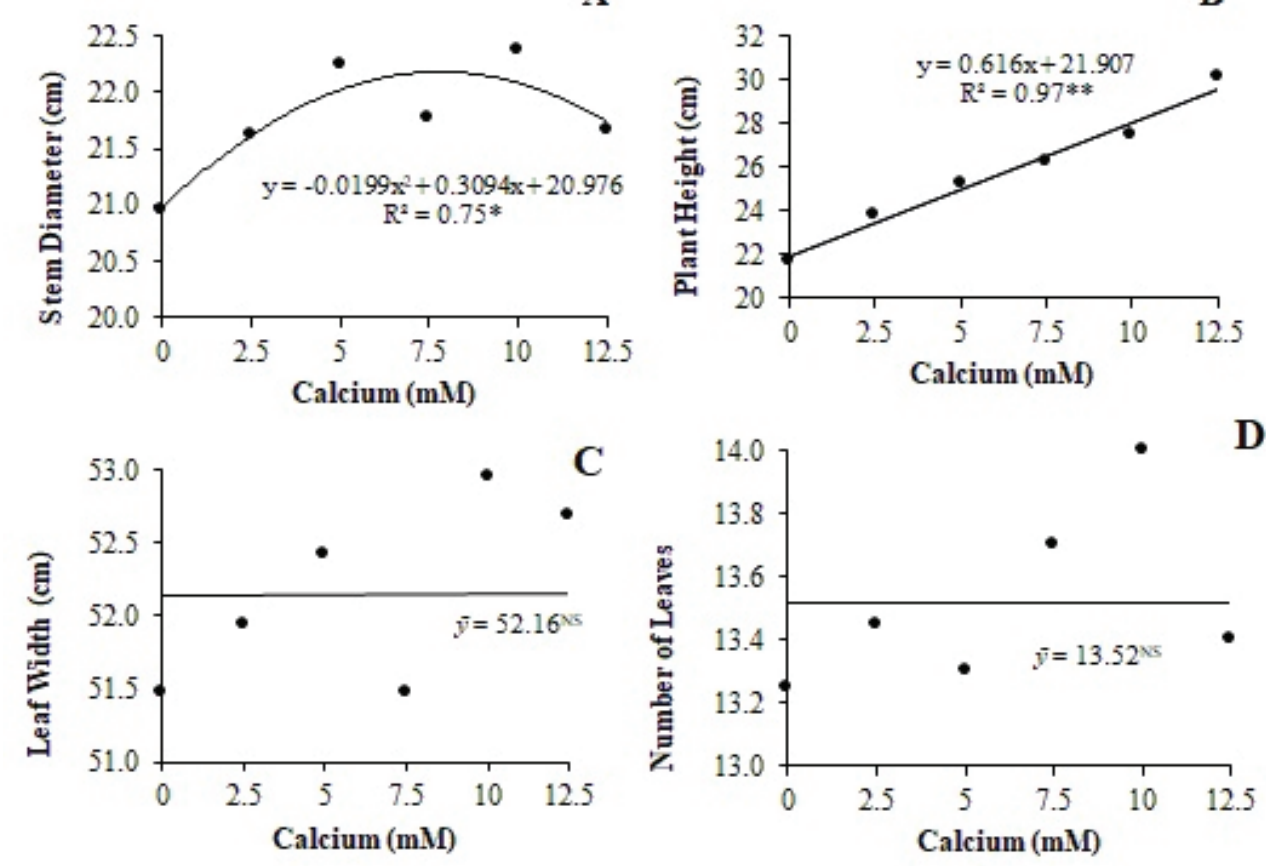

Figure 1. Averages and adjusted curve for variables stem diameter (A), plant height (B), leaf width (C), number of leaves (D) of silver vase bromeliad (Aechmea fasciata) cultivated on HA solution n.1

(Hoagland and Arnon, 1950) supplemented with 0.25, 2.5, 5.0, 7.5, 10.0 or $12.5 \mathrm{mM} \mathrm{Ca} . * *=(0.01<\mathrm{p} \leq 0.01) ; *=(0.01<\mathrm{p} \leq 0.05) ; \mathrm{NS}=$ Not Significant.

Calcium is an important plant nutrient that affects the formation of cell membrane and plasma membrane and plays a fundamental role in plant growth, biomass production and function (Madani et al., 2015), which might explain the increase on mass production of silver vase bromeliad. In vitro cultivated bromeliads of Vriesea genus had significantly increase in fresh and dry masses as the calcium in solutions augmented; as $\mathrm{Ca}$ facilitated the absorption of other nutrients such $\mathrm{N}, \mathrm{K}, \mathrm{Zn}, \mathrm{Mn}$, and $\mathrm{B}$ resulting on better nutritional status consequently enhancing plant growth (Aranda-Perez et al., 2009). Calcium also have a major influence on cell metabolism, cell wall structure and integral part of the cell wall, it is involved in cross linkage of pectic molecules, promoting plant growth and development (Saikia et al., 2018). However, Aechmea blanchetiana cultivated in vitro under different calcium concentrations $(1.5 \leq \mathrm{Ca} \leq 12 \mathrm{mM})$ showed a decrease in root growth due to the presence of chlorine $(\mathrm{Cl})$ on culture media (Kanashiro et al., 2009).

Leaf fresh (Figure 2A; $<<0.01$ ) and dry (Figure 2B; $\mathrm{p}<$ 0.05 ) masses, and total fresh (Figure $2 \mathrm{C} ; \mathrm{p}<0.01$ ) and dry (Figure 2D; $<<0.05$ ) masses increased as the concentration of calcium was raised in HA medium. Stem fresh (Figure $2 \mathrm{E} ; \mathrm{p}>0.05$ ) and dry (Figure $2 \mathrm{~F} ; \mathrm{p}>0.05$ ) masses, root fresh (Figure 2G; $\mathrm{p}>0.05$ ) and dry (Figure 2H; $\mathrm{p}>0.05$ ) masses did not show significant difference with increasing concentrations of calcium. Fresh and dry root mass did not differ statistically (Figures 2E and 2F). 
A

B
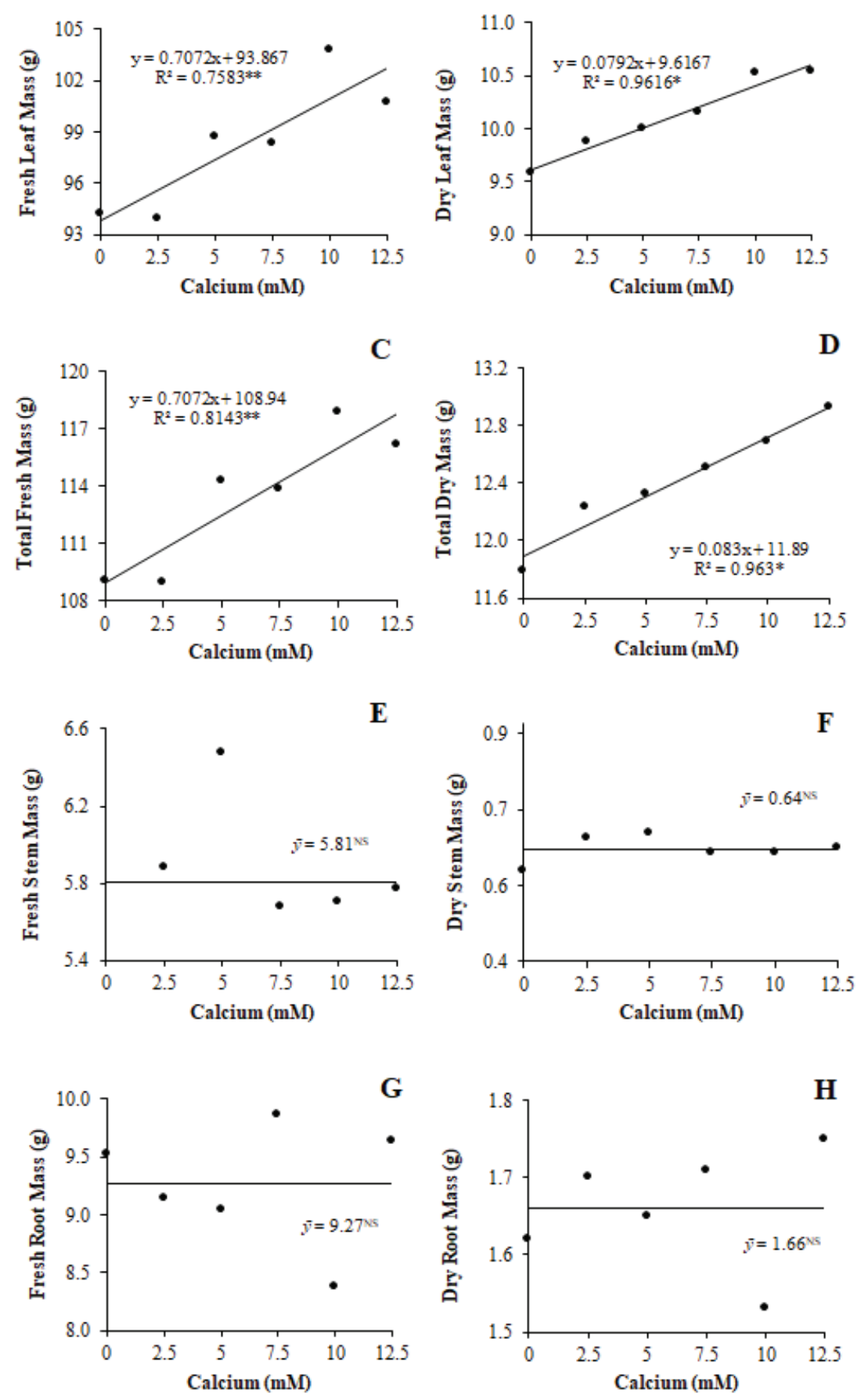

Figure 2. Averages and adjusted curve for variables fresh (A) and dry (B) leaf mass; fresh (C) and dry (D) total mass; fresh (E) and dry (F) stem mass; fresh (G) and dry (H) root mass of silver vase bromeliad (Aechmea fasciata) cultivated on HA solution n.1 (Hoagland and Arnon, 1950) supplemented with 0.25, 2.5, 5.0, 7.5, 10.0 or 12.5 mM Ca. $* *=(0.01<\mathrm{p} \leq 0.01) ; *=(0.01<\mathrm{p} \leq 0.05) ; \mathrm{NS}=$ Not Significant.

Aranda-Peres et al. (2009) observed the highest data for dry and fresh masses of Vriesea friburguensis, V. unilaterais and V. hieroglyphica (Bromeliaceae) in vitro cultured, when used $12 \mathrm{mM} \mathrm{Ca}$ in Murashige and Skoog (MS) media, and Aechmea blanchetiana plantlets cultured in vitro in MS modified media with $9.38 \mathrm{mM} \mathrm{Ca}$ had an increase in fresh and dry masses (Kanashiro et al., 2009). Silver vase bromeliad did not show visual symptoms of calcium deficiency in leaves (Figure 3). 


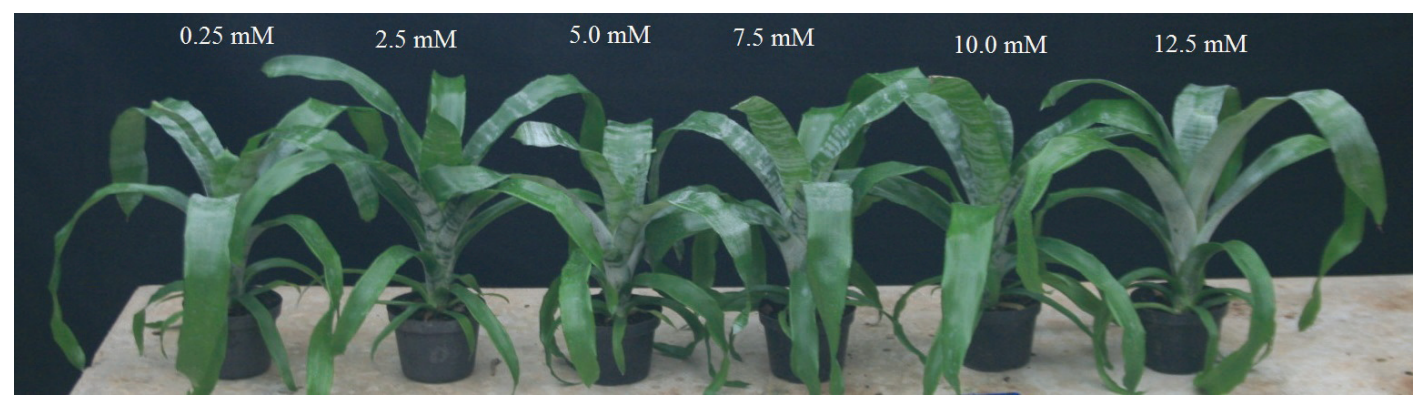

Figure 3. Silver vase bromeliad (Aechmea fasciata) fertilized with different calcium concentrations in HA solution n.1 (Hoagland and Arnon, 1950) modified with 0.25, 2.5, 5.0, 7.5, 10 or $12.5 \mathrm{mM} \mathrm{Ca.}$

Silver vase bromeliads cultivated under $\mathrm{Ca}$ omission or complete Hoagland and Arnon medium (1950) did not show difference on plant growth and plants submitted $\mathrm{Ca}$ omission do not exhibit visual symptoms of $\mathrm{Ca}$ deficiency (Young et al., 2018), corroborating our results. Ca deficiency symptoms in pineapple initially are observed on the fruit because the demand for calcium is highest at the time of floral differentiation (Malézieux and Bartholomew, 2003).
The increase of $\mathrm{Ca}$ in fertilizer solutions also increase $\mathrm{Ca}$ contents in leaves of silver vase bromeliad; conversely, $\mathrm{N}$, $\mathrm{P}$ and $\mathrm{Mg}$ contents in leaves decreased (Table 2), showing an antagonism effect. Young et al. (2018) observed lower values of $\mathrm{Ca}$ contents in leaves of silver vase bromeliads on treatment with $\mathrm{Ca}$ omission $\left(3.66 \mathrm{~g} \mathrm{~kg}^{-1}\right)$ and the equivalent Ca content as observed on our data on complete treatment $\left(13.00 \mathrm{~g} \mathrm{~kg}^{-1}\right)$.

Table 2. Macronutrients nitrogen $(\mathrm{N})$, phosphorus $(\mathrm{P})$, potassium $(\mathrm{K})$, calcium $(\mathrm{Ca})$, magnesium $(\mathrm{Mg})$ and sulfur $(\mathrm{S})$, and micronutrients boron $(\mathrm{B})$, cooper $(\mathrm{Cu})$, iron $(\mathrm{Fe})$, manganese $(\mathrm{Mn})$ and zinc $(\mathrm{Zn})$ contents in leaves of silver vase bromeliad cultivated on HA solution n.1 (Hoagland and Arnon, 1950) supplemented with $0.25,2.5,5.0,7.5,10.0$ or $12.5 \mathrm{mM} \mathrm{Ca}$.

\begin{tabular}{|c|c|c|c|c|c|c|c|c|c|c|c|}
\hline \multirow[t]{2}{*}{$\mathrm{Ca}(\mathrm{mM})$} & \multicolumn{6}{|c|}{ macronutrient $\left(\mathrm{g} \mathrm{kg}^{-1}\right)$} & \multicolumn{5}{|c|}{ micronutrient (mg kg-1) } \\
\hline & $\mathrm{N}$ & $\mathrm{P}$ & $\mathrm{K}$ & $\mathrm{Ca}$ & $\mathrm{Mg}$ & S & B & $\mathrm{Cu}$ & $\mathrm{Fe}$ & $\mathrm{Mn}$ & $\mathrm{Zn}$ \\
\hline 0.25 & 21 & 2.4 & 22 & 9 & 4.8 & 0.8 & 26 & 5 & 143 & 368 & 27 \\
\hline 2.5 & 20 & 2.3 & 22 & 9 & 4.3 & 0.8 & 26 & 5 & 116 & 357 & 29 \\
\hline 5.0 & 19 & 2.1 & 23 & 9 & 4.0 & 0.7 & 24 & 5 & 195 & 302 & 36 \\
\hline 7.5 & 18 & 2.1 & 22 & 10 & 4.3 & 0.8 & 23 & 5 & 126 & 345 & 22 \\
\hline 10.0 & 17 & 2.0 & 22 & 11 & 3.8 & 0.8 & 24 & 5 & 132 & 324 & 23 \\
\hline 12.5 & 17 & 1.8 & 22 & 13 & 3.8 & 0.8 & 23 & 5 & 192 & 340 & 22 \\
\hline
\end{tabular}

The decrease of the average of $\mathrm{P}, \mathrm{Mg}$ and $\mathrm{B}$ contents in plants is due to the antagonism between $\mathrm{Ca}$ and these nutrients, affecting their absorption (Malavolta, 1980). The interaction between calcium and phosphate is complex once both support and counteract each other, with simultaneous uptake and translocation of $\mathrm{Ca}$ and $\mathrm{P}$ and this effect is caused by precipitation of less soluble calcium phosphates at the area of nutrient-absorbing roots (Jakobsen, 1993). Increase of $\mathrm{CaCl}_{2}$ and $\mathrm{CaSO}_{4}$ concentrations in nutrient solution caused a decrease on $\mathrm{Mg}$ and an increase in $\mathrm{Ca}$ contents in cowpea (Vigna unguiculata) leaves and was attributed to an antagonistic effect of Ca on $\mathrm{Mg}$ (Guimarães et al., 2012). The liming increases the exchangeable Ca and $\mathrm{Mg}$ contents in the soil, which contributes to the increase in the leaf tissue of the pineapple (Veloso et al., 2001). The levels of boron (Table 2) contents in leaves of silver vase bromeliad decreased with augment of calcium concentrations in the solutions, showing the antagonistic effect. The copper content (Table 2) remained constant and the iron content (Table 2) showed a growth trend, showing the synergism effect. The macro e micronutrients contents in leaves of silver vase bromeliads are inside the range of chemical composition proposed by Poole and Conover (1976), exception for K contents that were almost three times higher in our study. Comparing our results with Mills and Jones (1996) recommendation silver vase bromeliads cultivated with 10.0 and $12.5 \mathrm{mM}$ Ca presented $\mathrm{Mg}, \mathrm{B}$ and $\mathrm{Zn}$ deficiency, and plants cultivated with $7.5 \mathrm{mM} \mathrm{Ca}$ were $\mathrm{B}$ and $\mathrm{Zn}$ deficient. Besides $\mathrm{Ca}$ concentrations, the Ca source is also important for Bromeliaceae, once large amounts of lime can raise soil $\mathrm{pH}$ to levels which increase the incidence of root and heart rot in pineapple while gypsum and basaltic dust do not increase soil $\mathrm{pH}$ and thus not affecting root health (Silva et al., 2006). 


\section{Conclusions}

The data obtained in the experiment validate calcium as an important element to stimulate silver vase bromeliad growth. The concentration $12.5 \mathrm{mM} \mathrm{Ca}$ on nutrient solution is recommended for silver vase bromeliad fertilization.

\section{Author Contribution}

CBM 0000-0002-3657-4570: conception and design of the research, analyze and interpretation of data and critically analyses of manuscript. VRS 0000-0003-4202-9373: analyze and interpretation of data, statistical analysis, write and critically analyses of

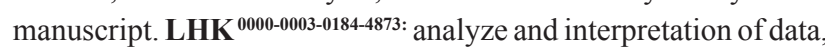
statistical analysis, write and critically analyses of manuscript. RJK 0000-0002-5810-406X: ionic balance calculations of nutrient solutions, conception, design and of the research, analyze and interpretation of data and critically analyses of manuscript. SK 0000-0003-0118-1723: conception and design of the research, obtaining data, analyze and interpretation of data, statistical analysis, write and critically analyses of manuscript. ART 0000-0001-6006-4741: conception and design of the research, obtaining data, analyze and interpretation of data, statistical analysis, write and critically analyses of manuscript and financial and obtaining funding.

\section{Acknowledgments}

The authors thank CNPq (Conselho Nacional de Desenvolvimento Científico e Tecnológico) for the financial support (proc. 455929/2014-9) and for the productivity grant (306140/2012-8) of ART.

\section{References}

ANACLETO, A.; NEGRELLE, R.R.B. Extrativismo de rametes e propagação vegetativa de Aechmea nudicaulis (L.) Griseb. (Bromeliaceae). Scientia Agraria, v.10, n.1, p.85-88, 2009. DOI: http://dx.doi.org/10.5380/rsa. v10i1.13529

ARANDA-PERES, A.N.; PERES, L.E.P.; HIGASHI, E.N.; MARTINELLI, A.P. Adjustment of mineral elements in the culture medium for the micropropagation of three Vriesea bromeliads from the Brazilian Atlantic Forest: the importance of calcium. HortScience, v.44, n.1, p.106-112, 2009.

ENGLERT, S.I. Orquídeas e Bromélias: manual prático de cultivo. Guaíba: Agropecuária, 2000. 92p.

GUIMARÃES, F.V.A.; LACERDA, C.F.D.; MARQUES, E.C.; ABREU, C.E.B.D.; AQUINO, B.F.D.; PRISCO, J.T.; GOMES-FILHO, E. Supplemental $\mathrm{Ca}^{2+}$ does not improve growth but it affects nutrient uptake in NaCl-stressed cowpea plants. Brazilian Journal of Plant Physiology, v.24, n.1, p.9-18, 2012. DOI: http://dx.doi.org/10.1590/ S1677-04202012000100003
HEPLER, P.K. Calcium: a central regulator of plant growth and development. The Plant Cell, v.17, n.8, p.2142-2155, 2005. DOI: https://doi.org/10.1105/tpc.105.032508

HOAGLAND, D.R.; ARNON, D.L. The water culture methods for growing plants whitout soil (Bulletin, v. 347). Berkeley: California Agriculture Experiment Station, 1950. 1-32p.

JAKOBSEN, S.T. Interaction between plant nutrients: IV. Interaction between calcium and phosphate. Acta Agriculturae Scandinavica Section-B Plant Soil Sciences, v.43, n.1, p.6-10, 1993. DOI: https://doi. org/10.1080/09064719309410224

KANASHIRO, S.; RIBEIRO, R., R.C.S.; GONCALVES, A.N.; DEMETRIO, V.A.; JOCYS, T.; TAVARES, A.R. Effect of calcium on the in vitro growth of Aechmea blanchetiana (Baker) L.B . Smith plantlets. Journal of Plant Nutrition, v.32, n.5, p.867-877, 2009. DOI: https:// doi.org/10.1080/01904160902790341

KANASHIRO, S.; RIBEIRO, R.D.C.S.; GONÇALVES, A.N.; DIAS, C.T.S.; JOCYS, T. Efeitos de diferentes concentrações de nitrogênio no crescimento de Aechmea blanchetiana (Baker) L.B. Sm. cultivada in vitro. Hoehnea, v. 34, n. 1, p. 59-66, 2007. DOI: http://dx.doi.org/10.1590/ S2236-89062007000100003

MADANI, B.; WALL, M.; MIRSHEKARI, A.; BAH, A.; MOHAMED, M.T.M. Influence of calcium foliar fertilization on plant growth, nutrient concentrations, and fruit quality of papaya. HortTechnology, v.25, n.4, p.496$504,2015$.

MALAVOLTA, E. Elementos de Nutrição Mineral de Plantas. Ceres: Piracicaba, 1980. p.251.

MALAVOLTA, E.; VITTI, G.C.; OLIVEIRA, S.A. Avaliação do estado nutricional das plantas. Piracicaba: POTAFOS, 1997. p.319.

MALÉZIEUX, E., BARTHOLOMEW, D.P. Plant nutrition. In: The pineapple: botany, production and uses. Bartholomew, D.P., Paull, R.E., Rohrbach, K.G. New York: CABI Publishing, 2003. p.143-165.

MILLS, H.A.; JONES, J.B. Plant analysis handbook II: practical sampling, preparation, analysis, and interpretation guide. Athens: Micro-Macro Publishing, 1996. 422p.

NEGRELLE, R.R.B.; ANACLETO, A. Bromeliads wild harvesting in State of Paraná. Ciência Rural, v.42, n.6, p.981-986, 2012. DOI: http://dx.doi.org/10.1590/S010384782012000600005

PAULA, M.B.; MESQUITA, H.A.; NOGUEIRA, F.D. Nutrição e adubação do abacaxizeiro. Informe Agropecuário, v.19, n.195, p.33-39, 1998. 
PPOOLE, R.T.; CONOVER, C.A. Chemical composition of good quality tropical foliage plants. Proceedings of Florida State Horticultural Society, v.89, p.307-308, 1976.

PY, C.; LACOEUILHE, J.J.; TEISON, C. The pineapple, cultivation and uses. Paris: Maisonneuve \& Larose, 1987. $568 \mathrm{p}$.

SAIKIA, P.; TALUKDAR, M.C.; DAS, P. Optimization of zinc, magnesium and calcium on growth and flowering of Rhynchostylis Retusa L. Acta Scientific Agriculture, v.2, n.4, 2018.

SILVA, J.A., HAMASAKI, R., PAULL, R., OGOSHI, R., BARTHOLOMEW, D.P., FUKUDA, S., HUE, N.V., UEHARA, G. AND TSUJI, G.Y. Lime, gypsum, and basaltic dust effects on the calcium nutrition and fruit quality of pineapple. Acta Horticulturae, v.702, p.123131, 2006. DOI: 10.17660/ActaHortic.2006.702.15

SOUZA, L.F.S.; REINHARD, D.H. Pineapple. In: CRISÓSTOMO, L.A., NAUMOV, A. (Eds.). Fertilizing for high yield and quality tropical fruits of Brazil (IPI Bulletin 18). Horgen: International Potash Institute, 2007. pp. 179-201.
IVELOSO, C.A.C.; OEIRAS, A.H.L.; CARVALHO, E.J.M.; SOUZA, F.R.S. Resposta do abacaxizeiro à adição de nitrogênio, potássio e calcário em latossolo amarelo do nordeste paraense. Revista Brasileira de Fruticultura, v.23, n.2, p.396-402, 2001.

VIÉGAS, I.J.M.; SILVA, R.N.P.; SILVA, D.A.S.; OLIVEIRA NETO, C.F.; CONCEIÇÃO, H.E.O.; MASCARENHAS, G.S.; OKUMURA, R.S.; MONFORT, L.E.F.; SILVA, R.T.L. Mineral composition and visual symptoms of nutrients deficiencies in Curauá plants (Ananas comosus var. erectifolius). Australian Journal of Crop Science, v.8, n.5, p.747-753, 2014. DOI: 10.1590/ S0044-59672013000100006

YOUNG, J.L.M.; KANASHIRO, S.; JOCYS, T.; TAVARES, A.R. Silver vase bromeliad: Plant growth and mineral nutrition under macronutrients omission. Scientia Horticulturae, v.234, p.318-322, 2018. DOI: 10.1016/j. scienta.2018.02.002 